Buletin Ilmiah Keuangan dan Perbankan

Volume 6 - No. 2, November 2013

\title{
FAKTOR-FAKTOR YANG MEMPENGARUHI TINGKAT PENGEMBALIAN KREDIT USAHA RAKYAT (KUR) PADA PT. BANK RAKYAT INDONESIA (BRI) UNIT TALANG CABANG SOLOK
}

\author{
Afriyeni \\ (AKBP Padang) \\ afriyeni.yen@gmail.com
}

Abstract

This research conducted for analyze factors-factors what that affect the loan repayment rate people's business (KUR) on PT. Bank Rakyat Indonesia Unit Talang Branch Solok. Methods research using analysis descriptive, namely technique data processing which is done with the road collate systematically in the form of figuresfigures and or percentages, regarding an object who investigational, so that is obtained general conclusion. Based on the the results of research who conducted obtained by factors-factors which influencing loan repayment rate people's business (KUR) on PT. Bank Rakyat Indonesia Unit Talang Branch of Solok is factor credit characteristics namely factor number of loan, installment credit and subsequent payback periods credit.

Keywords : loan, repayment rate, credit characteristics.

\section{PENDAHULUAN}

Dilihat dari perkembangan dunia usaha yang semakin mengalami peningkatan baik di bidang pertanian, perindustrian, perdagangan dan jenis usaha lainnya, dimana di dalam pembiyaan perusahaan tidak dapat memenuhi dari modal sendiri saja dan memerlukan tambahan modal dari pihak lain. Salah satu lembaga keuangan yang memberikan pinjaman adalah bank. Dalam menjalankan usahanya bank mempunyai dua tugas pokok yang utama yaitu menghimpun dana dari masyarakat melalui deposito dan tabungan dan menyalurkan kembali dana tersebut kepada masyarakat melalui kredit. Pemberian kredit merupakan aktivitas utama bank dalam memperoleh keuntungan di samping kegiatan seperti tabungan, deposito, dan jasa-jasa lainnya.

Usaha Mikro, Kecil, dan Menengah (UMKM) merupakan salah satu sektor usaha yang paling banyak diminati oleh para pelaku usaha dan cukup prospektif untuk dikembangkan. UMKM dalam perekonomian nasional memiliki peran yang penting dan strategis serta terbukti sebagai sektor usaha yang mampu bertahan terhadap krisis ekonomi global yang sedang melanda kalangan usaha di tingkat internasional maupun kalangan usaha di Indonesia salah satunya di sektor agribisnis.

Menurut Ratnawati diacu dalam Ashari (2009) pada tahun 2002-2006 pangsa kredit perbankan untuk sektor pertanian rata-rata hanya $5,72 \%$, padahal perbankan memiliki potensi 
yang cukup besar dalam pembiayaan pertanian. Perbankan kurang antusias dalam menyalurkan kredit untuk pertanian karena sifat komoditas pertanian yang musiman sehingga pendapatan yang diperoleh petani tergantung dari hasil panen musiman, sedangkan pembayaran kredit dilakukan secara bulanan. Resiko pada bidang pertanian juga relatif tinggi, cuaca yang tidak menentu dan hama tanaman sering mengakibatkan tanaman rusak sehingga petani mengalami gagal panen. Selain itu, tidak adanya jaminan sebagai syarat pengajuan kredit serta kurangnya pemahaman petani terhadap administrasi perbankan menyebabkan petani kesulitan dalam mengakses kredit perbankan. Pemerintah sebagai salah satu pihak yang bertanggung jawab terhadap kesejahteraan petani, telah meluncurkan beberapa kredit program atau bantuan modal bagi petani dan pelaku usaha pertanian melalui beberapa pembiayaan pertanian salah satunya adalah Kredit Usaha Rakyat (KUR).

KUR merupakan kredit pertanian baru yang diluncurkan oleh pemerintah pada tanggal 5 November 2007. Program kredit ini bertujuan untuk membantu aksesibilitas kredit bagi para petani yang dikembangkan melalui kerjasama dengan beberapa bank komersil yang ditunjuk oleh pemerintah dengan plafon kredit sampai dengan 500 juta rupiah serta suku bunga maksimal sebesar 14 persen untuk KUR Ritel dan 22 persen untuk KUR mikro. Kredit Usaha Rakyat merupakan pembiayaan kepada Usaha Mikro, Kecil, Menengah, Koperasi (UMKM-K) dalam bentuk pemberian modal kerja dan investasi yang didukung fasilitas penjaminan untuk usaha produktif.KUR diperuntukkan bagi usaha produktif yang feasible namun belum bankable. Tujuan dari program KUR adalah untuk mempercepat pengembangan sektor-sektor primer dan pemberdayaan usaha skala kecil, untuk meningkatkan aksebilitas terhadap kredit dan lembaga-lembaga keuangan, mengurangi tingkat kemiskinan, dan memperluas kesempatan kerja.

Agunan pokok KUR adalah proyek yang dibiayai, sedangkan agunan tambahan sebagian di-cover oleh program penjaminan (PT. Askrindo dan Jamkrindo) sebesar 80 persen untuk sektor pertanian, kelautan dan perikanan, kehutanan dan industri, dan untuk KUR tenaga kerja Indonesia serta 70 persen untuk sektor lainnya. Hal ini dikarenakan UMKM pada umumnya jarang memiliki agunan tambahan.

Berikut data realisasi penyaluran Kredit Usaha Rakyat (KUR) yang disalurkan oleh beberapa perbankan nasional pada periode tahun 2008 sampai dengan tahun Januari 2011. 
Tabel 1.

Realisasi penyaluran Kredit Usaha Rakyat

Tahun 2008 - Januari 2011

\begin{tabular}{|c|c|c|c|c|c|c|c|c|c|c|}
\hline \multirow{3}{*}{ BANK } & \multicolumn{10}{|c|}{ REALISASI } \\
\hline & \multicolumn{2}{|c|}{ TAHUN 2008} & \multicolumn{2}{|c|}{ TAHUN 2009} & \multicolumn{2}{|c|}{ TAHUN 2010} & \multicolumn{2}{|c|}{$\begin{array}{l}\text { TAHUN } 2011 \\
\text { (Januari) }\end{array}$} & \multicolumn{2}{|c|}{ JUMLAH } \\
\hline & RP. M & $\begin{array}{l}\text { DEB } \\
\text { (Orang) }\end{array}$ & RP. M & $\begin{array}{l}\text { DEB } \\
\text { (Orang) }\end{array}$ & RP. M & $\begin{array}{l}\text { DEB } \\
\text { (Orang) }\end{array}$ & $\begin{array}{l}\text { RP. } \\
M\end{array}$ & $\begin{array}{l}\text { DEB } \\
\text { (Orang) }\end{array}$ & RP. M & $\begin{array}{l}\text { DEB } \\
\text { (Orang) }\end{array}$ \\
\hline BNI & 1527 & 11.567 & 1.630 & 16.257 & 3.348 & 49.316 & 186 & 1.835 & 6.693 & 78.975 \\
\hline BRI & 12841 & 2.316 .608 & 9.879 & 1.349 .505 & 16.796 & 1.717 .832 & 1.318 & 124.409 & 40.835 & 5.508 .354 \\
\hline MANDIRI & 1.505 & 36.798 & 2.100 & 37.311 & 3.396 & 77.079 & 40 & 244 & 7.043 & 151.432 \\
\hline BTN & 263 & 2.457 & 710 & 2.636 & 933 & 5.934 & 69 & 466 & 1.976 & 11.493 \\
\hline BUKOPIN & 669 & 3.140 & 245 & 3.179 & 170 & 1.291 & 2 & 29 & 1.086 & 7.639 \\
\hline BSM & 382 & 4.338 & 452 & 2.530 & 660 & 9.924 & 87 & 1.195 & 1.582 & 17.987 \\
\hline BPD & - & - & 2.211 & 26.232 & 3.697 & 48.538 & 195 & 2.883 & 6.104 & 77.653 \\
\hline JUMLAH & 17.189 & 2.374 .908 & 17.228 & 1.437 .650 & 29.002 & 1.909 .914 & 1.900 & 131.061 & 65.321 & 5.853 .533 \\
\hline
\end{tabular}

Sumber : Kementrian Negara Koperasi Dan UMKM

Dari tabel di atas menunjukkan bahwa hingga Januari tahun 2011 BRI merupakan bank penyalur KUR dengan jumlah plafon terbesar, yaitu Rp. 40.835 M. Jumlah debitur BRI didominasi oleh nasabah KUR Mikro yang jumlahnya mencapai 5.508.354 Orang dan merupakan jumlah terbesar dibandingkan dengan bank-bank penyalur KUR lainnya. Besarnya penyaluran KUR yang dilakukan oleh BRI tidak terlepas dari usaha BRI menjaring debitur hingga pelosok kecamatan serta pengetahuan pengelola terhadap sektor pertanian yang cukup baik.

Namun disisi lain dengan adanya program penjaminan KUR sebesar 80 persen untuk sektor pertanian, kelautan dan perikanan, kehutanan dan industri serta 70 persen untuk sektor lainnya yang dilakukan pemerintah membuat masyarakat tidak berusaha untuk mengembalikan pinjaman karena menganggap bahwa pemerintah telah bertanggung jawab atas utangnya tersebut, padahal banyak diantara mereka yang sebenarnya mampu mengembalikan hutang, hal ini sering mengakibatkan kredit macet pada bank. Selain itu, kredit macet juga dapat terjadi karena ketidakmampuan nasabah dalam mengembalikan kredit. Ketidakmampuan nasabah membayar angsuran pokok pinjaman dan bunga yang dibebankan sesuai yang diperjanjikan dapat menyebabkan nilai tunggakan rill atau NPL (Non Performing Loan) pada suatu bank menjadi tinggi.

Batas NPL KUR Mikro di BRI tidak boleh lebih dari 4 persen, jika lebih dari itu maka BRI tersebut kemungkinan besar tidak diperbolehkan untuk menyalurkan KUR Mikro. Permasalahan NPL berkaitan dengan faktor-faktor yang berpengaruh terhadap pengembalian kredit. Faktor-faktor ini diturunkan dari prinsip 5C yang digunakan untuk menganalisis layak atau tidaknya nasabah menerima kredit, yaitu Character, Capacity, Collateral, Capital, dan Condition of Economy. 
Pada PT.BRI Unit Talang Cabang Solok, tingkat NPL mengalami kenaikan dari tahun ke tahun yaitu tahun 2008 jumlah outstanding NPL
Rp.18.715.931, dilanjutkan tahun 2009 outstanding Rp.35.050.800, dan tahun 2010 outstanding Rp.191.564.727.

Tabel 2.

Nilai Tunggakan Rill atau NPL (Non Perfoming Loan) KUR Mikro BRI Unit Talang Cabang Solok

Tahun 2008-2010

\begin{tabular}{|l|c|c|c|c|c|c|}
\hline \multicolumn{1}{|c|}{ Kategori } & \multicolumn{1}{|c|}{ Tahun } & \multicolumn{1}{c|}{2008} & \multicolumn{2}{c|}{ Tahun } & \multicolumn{2}{c|}{2009} \\
\hline & $\begin{array}{c}\text { Outstanding } \\
(\mathrm{Rp})\end{array}$ & $\begin{array}{c}\text { NPL } \\
(\mathrm{Rp})\end{array}$ & $\begin{array}{c}\text { Outstanding } \\
(\mathrm{Rp})\end{array}$ & $\begin{array}{c}\text { NPL } \\
(\mathrm{Rp})\end{array}$ & $\begin{array}{c}\text { Outstanding } \\
(\mathrm{Rp})\end{array}$ & $\begin{array}{c}\text { NPL } \\
(\mathrm{Rp})\end{array}$ \\
\hline Lancar & 1.514 .133 .131 & - & 3.372 .919 .200 & - & 4.573 .686 .316 & - \\
\hline Diragukan & 256.254 .000 & 10.779 .391 & 456.141 .756 & 20.484 .600 & 836.580 .000 & 159.443 .007 \\
\hline $\begin{array}{l}\text { Dipertimban } \\
\text { gkan }\end{array}$ & 8.265 .100 & 3.987 .640 & 10.379 .950 & 6.235 .600 & 15.326 .000 & 13.365 .000 \\
\hline $\begin{array}{l}\text { Kurang } \\
\text { Lancar }\end{array}$ & 13.254 .000 & 2.023 .600 & 19.221 .300 & 4.782 .000 & 25.365 .200 & 10.698 .120 \\
\hline Macet & 2.365 .100 & 1.925 .300 & 5.455 .500 & 3.548 .600 & 10.125 .650 & 8.058 .600 \\
\hline Total & 1.794 .271 .331 & 18.715 .931 & 3.864 .117 .706 & 35.050 .800 & 5.461 .083 .166 & 191.564 .727 \\
\hline
\end{tabular}

Sumber : BRI Unit Talang Cabang Solok

Pengembalian tunggakan KUR Mikro di BRI Unit Talang Cabang Solok terus mengalami kenaikan dari tahun ke tahun. Berdasarkan hal diatas, maka penulis tertarik meneliti lebih dalam tentang Faktor-faktor apa sajakah yang mempengaruhi tingkat pengembalian kredit usaha rakyat (KUR) mikro pada PT Bank Rakyat Indonesia Unit Talang Cabang Solok.

\section{KAJIAN TEORITIS DAN HIPO- TESIS}

Bank merupakan institusi keuangan yang mapan bagi perusahaan, badan-badan pemerintah dan swasta maupun perorangan untuk menyimpan atau mendapatkan dana melalui kegiatan perkreditan dan berbagai jasa yang diberikan. Definisi bank Menurut pasal 1 Bab 1 UU RI No. 10 Tahun 1998 tentang perubahan UU No. 7 Tahun 1992 (1999 : 9) Tentang Perbankan dinyatakan bahwa bank adalah badan usaha yang menghimpun dana dari masyarakat dalam bentuk simpanan dan menyalurkan kepada masyarakat dalam bentuk kredit dan bentuk lainnya dalam rangka meningkatkan taraf hidup rakyat banyak.

Menurut Suyatno (1997) pengertian bank adalah suatu badan yang bertujuan untuk melayani kebutuhan kredit baik dengan alat-alat pembayaran sendiri atau uang yang diperoleh dari orang lain maupun dengan jalan mengedarkan alat-alat penukaran baru berupa uang giral.

\section{Pengertian dan Karakteristik Usaha Mikro, Kecil dan Menengah (UMKM)}


Usaha Mikro, Kecil dan Menengah yang biasa disingkat dengan UMKM merupakan salah satu sektor ekonomi masyarakat yang cukup penting. Perkembangan usaha mikro, kecil dan menengah yang meningkat memerlukan upaya yang serius dari pemerintah dan pihak-pihak terkait lainnya untuk dapat membina dan melindungi agar nantinya UMKM dapat menjadi sektor unggulan bagi perekonomian Indonesia.

Usaha mikro merupakan kegiatan ekonomi masyarakat yang berskala kecil dan masih bersifat tradisional, dalam artian belum terdaftar, belum tercatat dan belum memiliki badan hukum. Usaha kecil adalah kegiatan ekonomi rakyat berskala kecil dan memenuhi kriteria kekayaan bersih atau hasil penjualannya tahunan serta kepemilikan sebagaimana diatur dalam Undangundang Republik Indonesia Nomor 9 Tahun 1995. Penjelasan mengenai usaha kecil tradisional pada pasal ini adalah usaha yang menggunakan alat produksi sederhana yang telah digunakan secara turun temurun, atau berkaitan dengan seni dan budaya. Adapun kriteria usaha kecil adalah memiliki kekayaan bersih paling banyak Rp 200.000.000,- tidak termasuk tanah dan bangunan tempat usaha, memiliki hasil penjualan tahunan paling banyak $\mathrm{Rp} 1.000 .000 .000,-$ dan sudah berbentuk usaha perorangan. Usaha menengah atau besar adalah kegiatan ekonomi yang mempunyai kriteria kekayaanbersih atau hasil penjualan tahunan lebih besar daripada kekayaan bersih dan hasil penjualan tahunan usaha kecil. Berdasarkan instruksi presiden Republik Indonesia Nomor 10 Tahun 1999 tentang pemberdayaan Usaha Menengah memberlakukan kriteria usaha menengah yaitu memiliki kekayaan bersih lebih besar dari Rp 200.000.000,sampai dengan paling banyak $\mathrm{Rp}$
10.000.000.000,- tidak termasuk tanah dan bangunan tempat usaha dan sudah berbentuk usaha perorangan.

Berdasarkan aspek komoditas yang dihasilkan, UMKM memiliki karakteristik tersendiri, yaitu :

1. Kualitasnya belum memenuhi standar, hal ini disebabkan karena sebagian besar UMKM belum memiliki teknologi yang seragam dan biasanya produk yang dihasilkan dalam bentuk handmade (manual) sehingga dari sisi kualitas relatif beragam.

2. Keterbatasan desain produk yang dimiliki oleh produk UMKM karena keterbatasan pengetahuan dan pengalamannya tentang produk karena selama ini UMKM bekerja didasarkan pada order, tidak banyak yang berani berkreasi dengan mencoba desain baru.

3. Terbatasnya jenis produk, biasanya UMKM hanya memproduksi sejenis atau terbatas sehingga apabila ada permintaan model baru dari buyer sulit untuk memenuhi karena kesulitan dalam penyesuaian dan waktunya biasanya sangat panjang untuk memenuhi order tersebut.

4. Terbatasnya kapasitas dan price list produknya, biasanya kapasitas produk yang sulit untuk ditetapkan dan harga yang tidak terukur dapat menyulitkan para pembeli atau konsumen.

Kredit merupakan bentuk penyaluran dana yang dilakukan oleh perbankan kepada masyarakat dengan tujuan agar dana dapat tersalurkan bagi mereka yang membutuhkan. Salah satu bentuk kredit yang diberikan adalah penambahan modal kerja kepada usaha agribisnis. Pemerintah sendiri mulai memperkenalkan kredit program bagi agribisnis sejak pendirian padi sentra (tahun 1959) yang menangani penyuluhan, penyaluran dan pemberian 
kredit. Kredit tersebut diperuntukan bagi pembelian sarana produksi dan uang untuk biaya hidup (cost of living). Setelah itu barulah mulai muncul program Bimas pada tahun 1966, dimana pemerintah membenahi system kelembagaan perkreditan untuk mendukung program intensifikasi padi.

Istilah kredit berasal dari bahasa yunani (credere) yang berarti kepercayaan, sehingga dasar dari kredit adalah kepercayaan. Menurut Suyatno (2007), unsur-unsur yang terdapat dalam kredit meliputi :

a. Kepercayaan, yaitu keyakinan si pemberi kredit bahwa segala prestasi yang diberikannya dalam bentuk uang, barang, atau jasa akan diterima kembali dalam jangka waktu tertentu di masa yang akan datang.

b. Waktu, yaitu suatu masa yang memisahkan antara pemberian prestasi dengan kontraprestasi yang akan diterima di masa yang akan datang.

c. Degree of risk, yaitu tingkat risiko yang akan dihadapi sebagai akibat dari adanya jangka waktu yang memisahkan antara pemberian prestasi dengan kontraprestasi yang akan diterima di masa yang akan datang.

d. Prestasi, yaitu objek kredit yang diberikan tidak hanya berupa uang, tetapi juga berupa barang ataupun jasa.

Pemberian kredit oleh perbankan dimaksudkan untuk memperoleh keuntungan, sehingga bank hanya boleh meneruskan simpanan masyarakat kepada nasabahnya dalam bentuk kredit jika debitur yang akan memperoleh kredit dipercaya mampu dan mau mengembalikan kredit. Pada dasarnya, tujuan bank memberikan kredit kepada debitur adalah :

a. Turut menyukseskan program pemerintah di bidang ekonomi dan pembangunan (kepentingan pemerintah).

b. Meningkatkan aktivitas perusahaan agar dapat menjalankan fungsinya guna menjamin terpenuhinya kebutuhan masyarakat (kepentingan masyarakat).

c. Memperoleh laba agar kelangsungan hidup perusahaan dapat terjamin dan dapat memperluas perusahaannya (pemilik modal/pengusaha).

\section{Kredit Bermasalah}

Kredit bermasalah merupakan kredit yang dikategorikan sebagai kredit yang pembayarannya tidak lancar. Hal ini dapat terjadi jika debitur tidak mampu memenuhi kewajibannnya dalam membayar angsuran kredit serta bunganya sesuai dengan perjanjian yang telah disepakati. Kolektibilitas kredit digolongkan menjadi lima kategori :

1. Kredit Lancar

2. Kredit Kurang Lancar (jumlah tunggakan selama dua bulan)

3. Kredit Dipertimbangkan (jumlah tunggakan selama tiga bulan)

4. Kredit diragukan ( jumlah tunggakan selama enam bulan lebih)

5. Kredit Macet (jumlah lebih dari Sembilan bulan)

Berbagai implikasi yang mungkin terjadi membuat pihak bank harus segera mengatasi kredit bermasalah agar tidak mengalami kerugian. Menurut Dendawijaya (2001), pihak bank dapat melakukan berbagai tindakan penyelamatan dengan cara berikut :

1. Rescheduling, tindakan bank melakukan penyelamatan dengan cara menyusun ulang jadwal pelunasan kewajiban debitur yang berupa pokok pinjaman serta bunganya.

2. Reconditioning, mengubah sebagian atau seluruh persyaratan yang semula disepakati antara debitur dan pihak 
bank serta dituangkan dalam perjanjian kredit.

3. Kombinasi $3 R$, yaitu dengan cara rescheduling-recondioning, rescheduling-restructuring, restructuring-reconditioning, dan rescheduling-restructuringreconditioning secara sekaligus.

4. Eksekusi, merupakan cara terakhir jika keempat cara di atas tetap tidak dapat membuat nasabah mampu memenuhi kewajibannya.

\section{Pengendalian Kredit}

Pada penyaluran kredit bank, perlu diperhatikan beberapa aspek yang terkait dengan nasabah penerima kredit untuk menghindari terjadinya kredit macet. Oleh karena itu, pihak bank perlu melakukan pengendalian kredit, yaitu usaha-usaha untuk menjaga kredit yang diberikan tetap lancar, produktif, dan tidak macet. Lancar, produktif, dan tidak macet berarti bahwa kredit beserta bunga yang telah diberikan kepada debitur dapat dikembalikan sesuai dengan perjanjian yang telah disetujui oleh kedua belah pihak. Penyaluran kredit harus didasarkan pada prinsip kehati-hatian serta pengendalian yang baik dan benar agar tidak terjadi kerugian pada pihak bank yang bersangkutan.

\section{Pertimbangan Kredit}

Pengendalian kredit dapat dilakukan sebelum merealisasikan kredit kepada debitur. Analisis yang biasa digunakan untuk mempertimbangkan pengajuan kredit yaitu prinsip 5C dan 7P. Menurut Hasibuan (2008), prinsip 5C meliputi :

1. Character (Watak), yaitu mengumpulkan informasi mengenai prilaku, kejujuran, pergaulan dan ketaatan calon debitur dalam memenuhi pembayaran transaksi.
2. Capacity (kemampuan), yaitu kemampuan calon debitur dalam memimpin perusahaan dengan baik dan benar.

3. Capital (modal), merupakan analisis tentang struktur dan besarnya modal yang terlihat dari neraca lajur perusahaan calon debitur.

4. Condition of Economy (kondisi perekonomian), yaitu pertimbangan terhadap kondisi perekonomian pada umumnya dan bidang usaha pemohon kredit pada khususnya.

5. Collateral (agunan), yaitu barangbarang yang akan digunakan oleh nasabah untuk membayar kredit jika terjadi kredit macet.

Selain prinsip 5C, prinsip lainnya yang digunakan bank sebagai pertimbangan untuk menyalurkan kredit kepada nasabah adalah prinsip 7P.

Menurut Hasibuan (2008), prinsip 7P meliputi :

1. Personalitiy (kepribadian) adalah sifat dan perilaku calon nasabah debitur yang mengajukan permohonan kredit kepada bank.

2. Party, yaitu menggolongkan nasabah ke dalam golongan tertentu berdasarkan modal, karakter, atau loyalitasnya.

3. Purposive (tujuan) merupakn tujuan dan penggunaan kredit yang diajukan oleh calon debitur kepada bank yang bersangkutan.

4. Prospect adalah prospek perusahaan $\mathrm{d}$ masa yang akan datang.

5. Payment (pembayaran) yaitu mengetahui bagaimana pembayaran kembali kredit yang diberikan dengan cara memperhitungkan kelancaran penjualan serta pendapatan calon debitur, sehingga bank dapat memperkirakan kemampuan calon debitur dalam mengembalikan kredit sesuai perjanjian. 
6. Profitability adalah menganalisis bagaimana kemampuan calon debitur dalam memperoleh laba.

7. Protection merupakan perlindungan yang berupa jaminan barang, jaminan orang, atau jaminan asuransi.

Hasibuan(2008) juga memaparkan prinsip 3R sebagai prinsip yang digunakan bank untuk memilih calon debitur. Prinsip 3R mencakup :

1. Returns adalah penilaian atas hasil yang akan diperoleh debitur setelah memperoleh kredit.

2. Repayment adalah kemampuan calon debitur dalam mengembalikan kredit sesuai dengan jumlah, jadwal, dan jangka waktu telah ditetapkan dalam perjanjian.

3. Risk Bearing Ability adalah kemampuan calon debitur dalam menghadapi risiko yang mungkin dihadapi dalam perusahaan sehingga mempengaruhi pengembalian kredit.

\section{Kinerja Kredit Usaha Rakyat (KUR)}

Dilihat dari sisi perbankan penyaluran KUR dapat memberikan beberapa manfaat yang dipetakan menjadi tiga hal, yaitu:

1. KUR dapat meningkatkan laba, namun tidak signifikan karena kecilnya nilai kredit KUR dibandingkan total kredit secara keseluruhan serta adanya kesulitan penyaluran KUR karena minimnya nasabah yang memenuhi syarat dan kurangnya SDM bank dalam penetrasi pasar ke kredit UMKM.

2. KUR dapat meningkatkan permintaan UMKM walaupun tidak perlu signifikan.

3. Pengaruh KUR rasio NPL KUR pada perbankan rata-rata kurang dari 1 persen dari total kredit mengingat kecilnya nilai kredit dan tingginya seleksi nasabah, namun ada beberapa bank yang tingkat NPL nya mencapai 10 persen dari total kredit.

Kendala yang dihadapi oleh perbankan dalam menyalurkan KUR adalah sulitnya memperoleh calon debitur yang sesuai dengan kriteria yang diinginkan oleh bank dan kerjasama dengan lembaga penjamin masih belum jelas. Sedangkan pada sisi UMKM, penyaluran KUR telah memberikan kesempatan pada pengusaha untuk mengembangkan usahanya ke arah yang lebih besar. Selain itu KUR juga menyebabkan peningkatan pemanfaatan tenaga kerja dan kesejahteraan UMKM.

Penelitian-penelitian yang terkait dengan pengembalian kredit telah banyak dilakukan diantaranya oleh Hasibuan (2010) yang meneliti tentang faktor-faktor yang mempengaruhi tingkat pengembalian kredit macet pada kredit usaha rakyat (KUR) sektor agribisnis di BRI Unit Talang, Cabang Solok. Hasil penelitian ini menunjukkan bahwa faktor-faktor yang mempengaruhi tingkat pengembalian kredit macet KUR adalah jangka waktu pengembalian kredit, beban bunga, dan omset usaha.

Penelitian mengenai faktorfaktor yang mempengaruhi tingkat pengem-balian kredit usaha rakyat (KUR) dilakukan oleh Agustania (2009) dan Lubis (2009). Agustania melakukan penelitian untuk menganalisis faktorfaktor yang mempengaruhi kelancaran pengembalian Kredit Usaha Rakyat (KUR) di Bank BRI Unit Cimanggis, Cabang Pasar Minggu. Hasil penelitian menunjukkan bahwa faktor-faktor yang berpengaruh nyata terhadap pengembalian KUR adalah omzet usaha, besarnya jumlah pinjaman, dan pinjaman lain. Berbeda dengan penelitian yang dilakukan oleh Agustania, penelitian yang dilakukan oleh Lubis pada BRI Unit Cibungbulang 
tidak hanya tentang faktor-faktor yang mempengaruhi pengembalian Kredit Usaha Rakyat, tetapi juga realisasi kreditnya. Hasil penelitian menunjukkan kredit bahwa variabel yang berpengaruh nyata terhadap realisasi dan pengembalian kredit adalah jenis kelamin dan kewajiban per bulan. Perbedaan penelitian ini dengan penelitian sebelumnya adalah dilihat dari variabel yang ada dalam penelitian sehingga adanya gambaran variabel penjelas lain yang mempengaruhi pengembalian KUR.

\section{Kerangka Pemikiran}

Bank Rakyat Indonesia (BRI)
merupakan salah satu lembaga
keuangan yang menyediakan
pembiayaan kepada UMKM. Visi BRI
yaitu menjadi bank komersial
terkemuka yang selalu mengutamakan
kepuasan nasabah. Sebagai langkah
realisasi dari visinya, salah satu misi
BRI adalah memberikan pelayanan
prima kepada nasabah melalui jaringan
kerja yang tersebar luas dan didukung

oleh sumber daya manusia yang profesional dengan melaksanakan praktek good corporate gorvernance. Oleh karena itu, BRI tidak hanya berada di wilayah perkotaan, tetapi juga memiliki unit hingga ke pelosok desa agar dapat menjangkau lapisan masyarakat kecil.

Salah satu program kredit pemerintah yang bernama Kredit Usaha Rakyat (KUR) merupakan program kredit yang disalurkan oleh beberapa bank yang di tunjuk oleh pemerintah, salah satunya adalah BRI. Sebagian besar bank menggunakan prinsip 5C sebagai pertimbangan untuk menyeleksi calon nasabah, seperti yang dilakukan oleh pihak BRI Unit Talang Cabang Solok.

Faktor-faktor yang diduga berpengaruh terhadap pengembalian kredit yaitu faktor-faktor berdasarkan karakteristik kredit seperti jumlah angsuran, jangka waktu pengembalian, dan jumlah pinjaman.

Kerangka pemikiran operasional dapat dilihat pada gambar 1 .

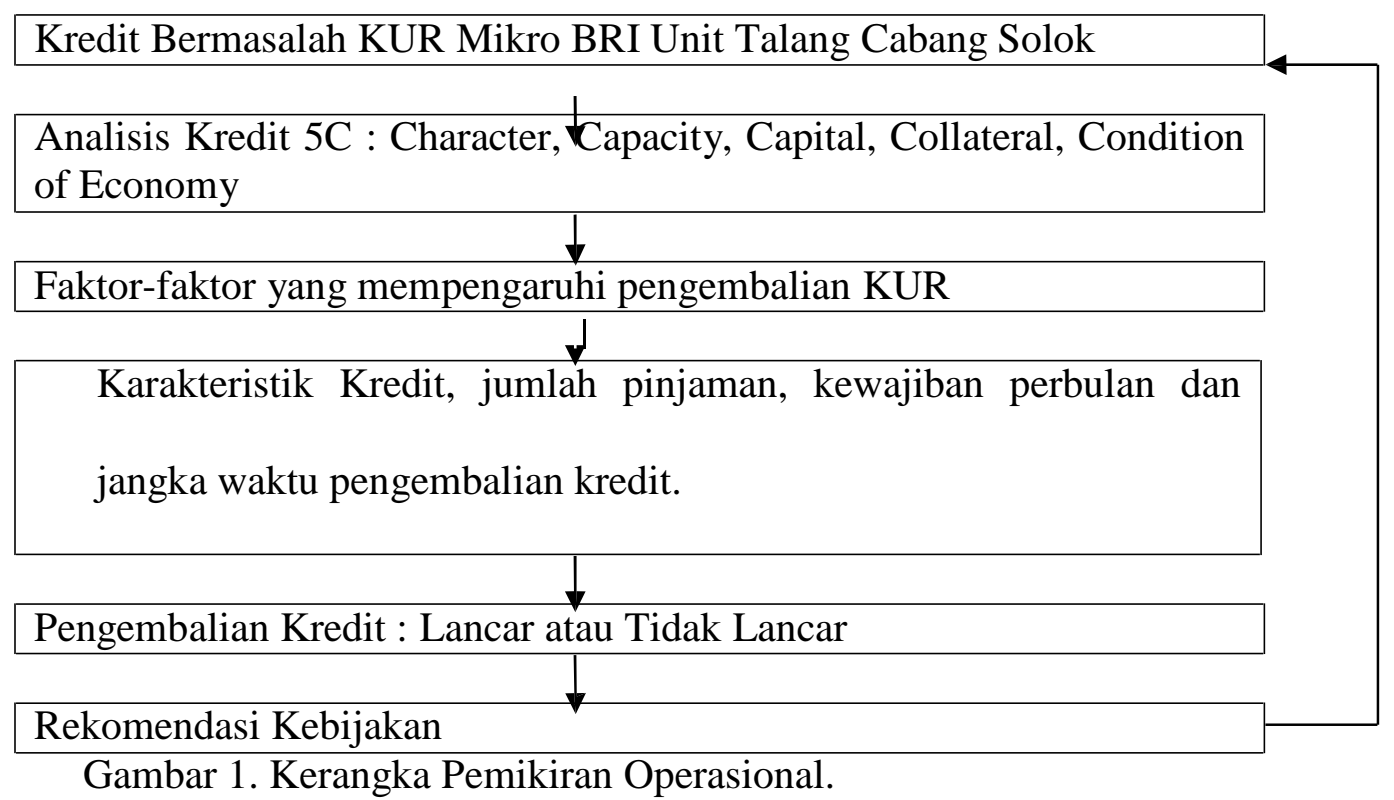




\section{METODOLOGI}

Penelitian ini dilakukan di PT BRI Unit Talang Cabang Solok. Pemilihan lokasi penelitian dilakukan secara purposive (sengaja). Penelitian ini menggunakan metode analisis deskriptif yaitu untuk mengetahui faktor-faktor apa sajakah yang mempengaruhi tingkat pengembalian Kredit Usaha Rakyat (KUR) pada PT. BRI Unit Talang Cabang Solok.

Data yang digunakan dalam penelitian ini adalah data primer dan data sekunder. Data primer diperoleh dari hasil diskusi peneliti dengan pihak manajemen BRI terkait dengan tata cara pembayaran kredit dan nasabah yang bermasalah dalam pengembalian kredit. Data sekunder yang digunakan berasal dari data internal BRI Unit Talang Cabang Solok ( $L w$ 315, dan dokumen permohonan kredit nasabah KUR), berkas nasabah KUR Mikro yang kemudian disesuaikan dengan fakta melalui wawancara dengan beberapa nasabah KUR Mikro serta data yang dikeluarkan oleh Kementerian Koperasi dan UMKM. Selain itu, data juga diperoleh dari artikel, jurnal penelitian, buku, skripsi, dan sumber lainnya yang terkait dengan penelitian.

\section{Metode Analisis Data}

Analisis data yang digunakan dalam penelitian ini adalah analisis data deskriptif kualitatif yaitu berupa deskripsi mengenai karakteristik kredit yang mempengaruhi pengembalian KUR Mikro di BRI Unit Talang Cabang Solok. Analisis deskriptif ini bertujuan untuk mengetahui karakteristik masyarakat (pelaku usaha mikro) yang menerima KUR Mikro serta mengetahui karakteristik antara debitur lancar dengan debitur yang tidak lancar (menunggak) dalam pengembalian kreditnya.
HASIL DAN PEMBAHASAN

Persyaratan, Mekanisme Penyaluran dan Cara Pembayaran KUR

KUR merupakan kredit program pemerintah dan BRI serta bank penyalur KUR lainnya dalam bentuk Kredit Modal Kerja (KMK) maupun Kredit Investasi (KI) dengan plafon kredit maksimal sebesar 500 juta rupiah. Namun, bagi usaha mikro plafon kredit maksimal KUR adalah 20 juta rupiah. KUR dimaksudkan untuk meningkatkan akses pembiayaan bagi UMKMK yang melakukan usaha produktif dan layak (feasible) namun belum bankable (tidak memenuhi syarat dalam hal agunan dan syarat perkreditan lain yang sesuai dengan ketentuan bank) yang sebagian dijamin oleh perusahaan penjamin. KUR bertujuan untuk tercapainya percepatan pengembangan sektor riil dan pemberdayaan UMKMK dalam rangka penanggulangan kemiskinan dan perluasan kesempatan kerja. Persyaratan KUR Mikro adalah sebagai berikut :

a. Calon debitur adalah individu yang melakukan usaha produktif yang layak.

b. Calon debitur memiliki legalitas yang lengkap dengan adanya KTP/SIM dan Kartu Keluarga.

c. Lama usaha minimal 6 bulan.

d. Plafon kredit maksimal Rp 20 juta.

e. Suku bunga efektif maksimal 22 persen per tahun.

f. Jangka waktu dan jenis kredit, untuk KMK maksimal 3 tahun dan KI maksimal 5 tahun. Dalam hal perpanjangan, suplesi, dan restrukturisasi jangka waktunya lebih lama, yaitu maksimal 6 tahun untuk KMK dan 10 tahun untuk KI.

g. Agunan pokok, dapat hanya berupa agunan pokok apabila sesuai keyakinan bank bahwa proyek yang dibiayai cash flow-nya mampu 
memenuhi seluruh kewajiban

kepada bank (layak). Agunan tambahan sesuai dengan ketentuan bank pelaksana.

Calon nasabah yang ingin mengajukan permohonan KUR harus mengikuti mekanisme penyaluran KUR yang telah ditetapkan oleh BRI. Mekanisme penyaluran KUR di BRI Unit Talang adalah sebagai berikut :

1. Calon nasabah datang ke kantor BRI Unit lalu bertemu dengan customer service untuk mengajukan permohonan KUR.

2. Berkas-berkas dari customer service diserahkan kepada kepala unit untuk diperiksa kelengkapannya.

3. Jika kelengkapan berkas sudah lengkap, kepala unit memberikan berkas-berkas tersebut kepada customer service yang kemudian memberikannya kepada mantri KUR untuk dianalisis.

4. Mantri KUR melakukan survei ke tempat usaha nasabah dan menilai kelayakan usahanya.

5. Mantri KUR memberikan laporan kepada kepala unit. Jika usaha tersebut layak untuk mendapatkan pembiayaan, keputusan pemberian kredit dilakukan oleh kepala unit.

Nasabah yang disetujui untuk mendapatkan pinjaman KUR harus mengembalikan pinjamannya dalam jangka waktu yang telah ditentukan sebelumnya. Pembayaran angsuran kredit dapat dilakukan dengan dua cara, yaitu:

1. Membayar angsuran langsung kepada teller.

2. Membayar angsuran dengan cara menitipkan uang angsuran kepada mantri KUR untuk kemudian dibayarkan kepada teller jika antrian teller penuh. Bagi nasabah yang menunggak, mantri KUR akan mendatangi

nasabah, kemudian nasabah

$$
\begin{aligned}
& \begin{array}{l}
\text { membayar angsuran } \\
\text { melalui }
\end{array} \\
& \text { KUR yang mendatanginya. }
\end{aligned}
$$

Pada bulan Desember 2012, total nasabah aktif KUR Mikro BRI Unit Talang Cabang Solok sebanyak 782 orang, yang terdiri dari 760 orang mengambil KMK (Kredit Modal Kerja) dan 22 orang mengambil KI (Kredit Investasi) dengan total kredit yang tersalurkan Mantri KUR yaitu sebesar Rp. 5.461.083.166

Faktor-faktor yang Mempengaruhi Tingkat Pengembalian Kredit Usaha Rakyat (KUR) Mikro Berdasarkan Karakteristik Kredit

Karakteristik kredit diidentifikasi berdasarkan beberapa faktor diduga berpengaruh, yaitu jumlah pinjaman, angsuran kredit per enam bulan, dan jangka waktu pengembalian kredit sebagai berikut :

\section{a. Jumlah Pinjaman}

Salah satu karakteristik yang digunakan dalam penelitian ini adalah jumlah pinjaman. Jumlah pinjaman adalah batas jumlah kredit yang diberikan oleh bank kepada debitur dalam satuan rupiah. Faktor ini berpengaruh negatif terhadap kelancaran pengembalian kredit. Semakin besar jumlah pinjaman yang diterima oleh debitur maka semakin besar jumlah angsuran dan bunga yang harus dibayarkan sehingga mempengaruhi kelancaran pembayaran pinjaman. Berikut data laporan jumlah nasabah lancar dan menunggak KUR Mikro BRI Unit Talang Cabang Solok menurut jumlah pinjaman dapat dilihat pada tabel 3 
Tabel 3

Jumlah Nasabah Lancar dan Menunggak KUR Mikro BRI Unit Talang menurut Jumlah Pinjaman pada Desembar Tahun 2012.

\begin{tabular}{|c|l|l|l|l|l|l|}
\hline \multirow{2}{*}{ Jumlah } & \multicolumn{2}{|c|}{ Lancar (Kolek 1) } & \multicolumn{2}{|l|}{$\begin{array}{l}\text { Menunggak (Kolek } \\
\mathbf{2 , 3 , 4 , 5})\end{array}$} & \multicolumn{2}{|c|}{ Total } \\
\hline Pinjaman & Org & $\begin{array}{l}\text { Jumlah } \\
\text { Kredit }\end{array}$ & Org & $\begin{array}{l}\text { Jumlah } \\
\text { Kredit }\end{array}$ & Org & $\begin{array}{l}\text { Jumlah } \\
\text { Kredit }\end{array}$ \\
\hline$<5 \mathrm{Jt}$ & 71 & 212.994 .900 & 13 & 26.226 .350 & 84 & 239.221 .250 \\
\hline $\begin{array}{l}6 \mathrm{Jt}- \\
10 \mathrm{Jt}\end{array}$ & 339 & 1.857 .662 .450 & 138 & 787.010 .539 & 477 & 2.644 .732 .989 \\
\hline$>10 \mathrm{Jt}$ & 169 & 2.082 .232 .150 & 45 & 494.956 .777 & 214 & 2.577 .188 .927 \\
\hline Total & 579 & 4.152 .889 .500 & 193 & 1.308 .193 .666 & 772 & 5.461 .083 .166 \\
\hline $\begin{array}{l}\text { Nilai } \\
\text { Maksi } \\
\text { mum }\end{array}$ & - & 20.000 .000 & - & 20.000 .000 & - & - \\
\hline $\begin{array}{l}\text { Nilai } \\
\text { Minim } \\
\text { um }\end{array}$ & - & 3.000 .000 & - & 3.000 .000 & & - \\
\hline \begin{tabular}{l} 
Sumber : \\
\hline T. BRI
\end{tabular} & & & & & \\
\hline
\end{tabular}

Sumber : PT. BRI Unit Talang Cabang Solok ( Lw 315).

Secara keseluruhan jumlah pinjaman berkisar antara tiga hingga dua puluh juta rupiah. Sebagian besar nasabah menerima kredit dengan nilai plafon enam sampai dengan sepuluh juta rupiah, termasuk debitur yang menunggak sebagian besar berada pada kisaran tersebut. Hal ini mengidentifikasikan bahwa pihak bank harus lebih berhati-hati dalam mencairkan dana pinjaman yang jumlahnya berkisaran antara enam sampai dengan sepuluh juta rupiah, jika usahanya dinilai berisiko tinggi, omset maupun Repayment Capacity (kapasitas pengembalian kredit yang dimiliki seorang nasabah yang nilainya sebesar 75 persen dari penghasilan bersih per bulan) yang dimilki nasabah jumlahnya kecil dari nilai angsuran pinjaman.

\section{b. Angsuran Kredit}

Karakteristik selanjutnya ada-lah angsuran kredit. Angsuran kredit per bulan merupakan jumlah angsuran pokok dan bunga yang harus dibayarkan oleh debitur setiap bulannya dalam jangka waktu peng-embalian yang telah ditentukan.

Angsuran kredit berpengaruh negatif terhadap kelancaran pengembalian kredit. Semakin besar angsuran yang harus dibayarkan debitur perbulannya maka semakin sulit bagi debitur untuk membayar angsuran tersebut akan lebih besar. Angsuran yang harus dibayarkan oleh debitur berkisar antara Rp. 280.800,hingga Rp. 1.871.700.

Berikut data laporan jumlah nasabah lancar dan menunggak KUR BRI Unit Talang menurut angsuran kredit per bulan dapat dilihat pada tabel 4. 
Tabel 4

Jumlah Nasabah Lancar dan Menunggak KUR Mikro BRI Unit Talang menurut Angsuran Kredit pada Tahun 2012

\begin{tabular}{|l|r|c|c|c|c|c|}
\hline Jumlah & \multicolumn{2}{|c|}{ Lancar (Kolek 1) } & \multicolumn{2}{c|}{$\begin{array}{l}\text { Menunggak } \\
\text { (Kolek 2,3,4,5) }\end{array}$} & \multicolumn{2}{c|}{ Total } \\
\hline Angsuran & Orang & $\%$ & Orang & $\%$ & Orang & $\%$ \\
\hline$<500$ ribu & 246 & 31.86 & 35 & 4.5 & 281 & 36.4 \\
\hline $\begin{array}{l}600 \text { ribu }- \\
\text { 1juta }\end{array}$ & 200 & 25.9 & 96 & 12.43 & 296 & 38.4 \\
\hline$>1$ juta & 133 & 17.22 & 62 & 8 & 195 & 26.2 \\
\hline $\begin{array}{l}\text { Total } \\
\text { Nilai } \\
\begin{array}{l}\text { Maksimu } \\
\text { m }\end{array}\end{array}$ & 579 & 75 & 193 & 25 & 772 & 100 \\
\hline $\begin{array}{l}\text { Nilai } \\
\text { Minimum }\end{array}$ & Rp.1.871.700,- & Rp.1.871.700,- & & \\
\hline
\end{tabular}

Sumber : PT. BRI Unit Talang Cabang Solok ( $L w 321)$.

Dari hasil data tersebut secara keseluruhan nilai terbesar berada pada jumlah angsuran kredit dengan kisaran angsuran di antara enam ratus ribu rupiah sampai dengan satu juta rupiah per bulan, sedangkan proporsi terbesar jumlah nasabah lancar berada pada kisaran angsuran antara lima ratus ribu rupiah, dan nasabah menunggak sebagian besar berkewajiban membayar angsuran antar tujuh ratus ribu sampai dengan satu jutaan per bulan. Pihak BRI Unit Talang harus lebih memperhitungkan jumlah pinjaman dan angsuran yang dibelrikan kepada nasabah sesuai dengan kapasitas pengembalian dan omset yang diterima oleh nasabah sehingga pihak BRI dapat membe-rikan pinjaman dalam jumlah besar jika nasabah memiliki omset dan kapasitas pengembalian yang tinggi.

\section{c. Jangka Waktu Pengembalian Kredit}

Seterusnya karakteristik jangka waktu pengembalian kredit. Jangka waktu pengembalian kredit adalah batas waktu yang diberikan oleh bank kepada debitur untuk membayar pinjamannya hingga lunas. Faktor ini berpengaruh positif terhadap pengembalian kredit. Semakin lama jangka waktu pengembalian kredit yang diberikan oleh bank kepada debitur akan memperkecil peluang debitur melakukan tunggakan karena semakin kecil jumlah angsuran yang harus dibayarkan debitur per bulannya. Berikut data jumlah nasabah lancar dan menunggak KUR Mikro BRI Unit Talang Cabang Solok menurut jangka waktu pengembalian kredit dapat dilihat pada tabel 4 . 
Tabel 5

Jumlah Nasabah Lancar dan Menunggak KUR Mikro BRI Unit Talang

Menurut Jangka Waktu Pengembalian pada Tahun 2012

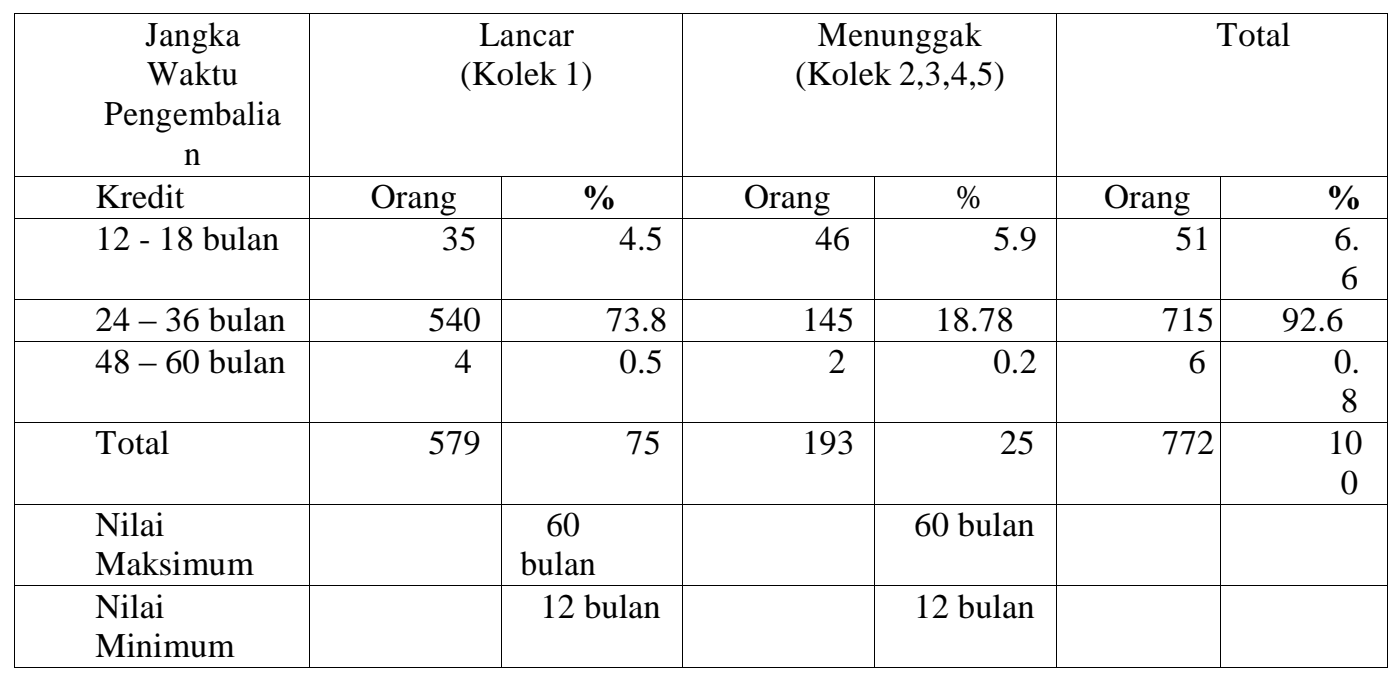

Sumber:PT. BRI Unit Talang Cabang Solok (Lw 321).

Sebagian besar nasabah dengan jangka waktu pengembaliannya berkisar antara 24 sampai 36 bulan, baik pada debitur lancar maupun menunggak. Hal ini menunjukan bahwa kemampuan nasabah PT. BRI Unit Talang untuk membayar jumlah angsuran dengan jangka waktu penpembalian kredit tersebut.

\section{SIMPULAN DAN IMPLIKASI}

Mekanisme penyaluran kredit usaha rakyat yang terdapat di BRI Unit Talang yang telah dapat dikatakan tidak terlalu sulit. Dimana nasabah hanya melengkapi berkas yang harus dipersiapkan seperti fotokopi KTP, pas foto, foto kopi kartu keluarga, fotokopi surat nikah, foto usaha dan surat keterangan usaha ditambah dengan jaminan tambahan apabila nasabah memiliki jaminan yang dapat digunakan sebagai pelengkap. Setelah memenuhi kelengkapan berkas nasabah selanjutnya akan diperiksa kelayakan usahanya dan selanjutnya akan ditentukan apakah nasabah tersebut akan mendapatkan pencairan pinjaman atau tidak. Pemeriksaaan usaha calon nasabah tidak terlepas dari prinsip-prinsip $5 \mathrm{C}$ (Character, Capacity, Capital, Collateral, dan Condition of Economy). Adapun prosedur yang menggunakan prinsip 5C ini dilakukan dengan tujuan untuk memperkecil besarnya tunggakan yang dapat terjadi nantinya setelah adanya pencairan KUR.

Faktor-faktor yang mempengaruhi tingkat pengembalian Kredit Usaha Rakyat (KUR) di BRI Unit Talang Cabang Solok salah satunya karakteristik kredit terdiri dari Jumlah pinjaman, Angsuran kredit dan Jangka waktu pengembalian kredit. Adapun Faktor lain yang diperhatikan sebelum melakukan pencairan kredit adalah Character nasabah. Adapun tujuannya adalah untuk mengetahui apakah nasabah yang akan diberikan pinjaman memiliki karakter yang baik atau tidak. 
Namun dalam hal ini nasabah yang diberi pinjaman KUR adalah nasabah baru dan karakter mereka hanya dapat diketahui pada saat melakukan pensurveian di lapangan. Kapasitas (Capacity) merupakan salah satu hal penting yang harus diperhatikan sebelum pencairan kredit. Mengetahui kapasitas dapat dilakukan dengan mengetahui pendapatan bersih rumah tangga dalam setahun. Semakin besar pendapatan bersih rumah tangga yang diperoleh dalam setahun akan memudahkan nasabah dalam pengembalian kredit kepada bank.

Berdasarkan hasil penelitian yang dilakukan diketahui bahwa karakteristik kredit yaitu jumlah pinjaman, angsuran kredit dan jangka waktu sangat berpengaruh terhadap tingkat pengembalian KUR di BRI Unit Talang Cabang Solok.

\section{Implikasi penelitian}

Dari hasil penelitian yang diperolemaka saran yang dapat disampaikan sebagai berikut :

1. BRI Unit Talang hendaknya meningkatkan daya serap KUR bagi nasabah dengan melakukan kegiatan sosialisasi yang berkaitan dengan KUR seperti menjelaskan apa itu KUR, siapa yang berhak mendapatkan KUR sehingga nantinya didapatkan pengusaha yang layak untuk menerima pinjaman dengan usaha yang memang layak untuk diberikan pinjaman pula.

2. BRI Unit Talang hendaknya lebih memperhatikan jumlah pinjaman yang akan diajukan sebagai realisasi pinjaman, karena dari sekian pinjaman yang berlangsung, jumlah nasabah KUR Unit Talang mengalami kenaikan.

3. BRI Unit Talang hendaknya lebih memperhatikan penghasilan nasabah dalam periode 1 bulan (RPC) sebagai pedoman pembayaran angsuran kredit perbulan nasabah.

4. BRI Unit Talang hendaknya memperhatikan jangka waktu pemberian kredit kepada nasabah karena dari data yang diperoleh nasabah yang bermasalah didominasi pinjaman yang mempunyai jangka waktu pengembalian anatara 24-36 bulan.

\section{DAFTAR PUSTAKA}

Agustania VI. 2009. Analisis FaktorFaktor yang Mempengaruhi Kelancaran Pengembalian Kre-dit Usaha Rakyat PT Bank BRI Unit Cimanggis Cabang Pasar Minggu, Skripsi. Bogor: Fakultas Ekonomi dan Manajemen, Institut Pertanian Bogor.

Dendawijaya L. 2001. Manajemen Perbankan.Jakarta: Ghalia Indonesia.

Handoyo M. 2009. Faktor-Faktor yang Mempengaruhi Tingkat Pengembalian Pembiayaan Syari'ah untuk UMKM Agribisnis pada KBMT Wihdatul Ummah Kota Bogor ,skripsi. Bogor: Fakultas Ekonomi dan Manajemen, Institut Pertanian Bogor.

Hasibuan R. 2010. Faktor-Faktor yang Mempengaruhi Tingkat Pengembalian Kredit Bermasa-lah pada Kredit Umum Pede-saan (KUR) yang terkait Sektor Agribisnis Unit Cijeruk. Bogor: Fakultas Pertanian, Institut Pertanian Bogor.

Kementerian Koperasi dan Usaha Kecil dan Menengah. 2012. Data Kredit Usaha Rakyat (KUR) per Desember 2012. Jakarta: Kementerian Koperasi dan Usaha Kecil dan Menengah. 
Lubis AM. 2009. Faktor-Faktor yang Mempengaruhi Relisasi dan

Pengembalian Kredit Usaha

Rakyat (Kasus : BRI Unit Cibungbulang) [skripsi]. Bogor: Fakultas Ekonomi dan Manajemen, Institut Pertanian Bogor.

PT. Bank Rakyat Indonesia. 2012. Data Kredit Usaha Rakyat (KUR) per Desember 2012. Solok: PT. Bank Rakyat Indonesia Unit Talang Cabang Solok.

Sari A. 2011. Analisis Faktor-faktor yang Mempengaruhi Pengembalian Kredit Usaha Mikro (Studi Kasus: BRI Unit Cibungbulang, Bogor) (Skripsi). Bogor: Fakultas Ekonomi dan Manajemen, Institut Pertanian Bogor.

Undang-Undang No. 10 Tahun 1998 Tentang Perubahan UndangUndang No. 7 Tahun 1992 Tentang Perbankan. 